Aleksandra Czapelska

Warszawa

\title{
Publikacje Instytutu Historii im. Tadeusza Manteuffla \\ Polskiej Akademii Nauk w Repozytorium Cyfrowym Instytutów Naukowych
}

Repozytorium Cyfrowe Instytutów Naukowych tworzy konsorcjum piętnastu instytutów Polskiej Akademii Nauk i jeden instytut resortowy, reprezentujących nauki humanistyczne, społeczne, przyrodnicze i ścisłe. Projekt jest finansowany od marca 2010 do marca 2014 r. z funduszy strukturalnych Unii Europejskiej, ze środków Programu Operacyjnego Innowacyjna Gospodarka Oś priorytetowa 2: infrastruktura strefy $\mathrm{B}+\mathrm{R}$, Działanie 2.3: Inwestycje związane z rozwojem infrastruktury informatycznej nauki Poddziałanie 2.3.2.: Projekty w zakresie rozwoju zasobów informatycznych nauki w postaci cyfrowej. Strona główna projektu znajduje się pod adresem www.rcin.org.pl.

W założeniu RCIN nie tylko uzupełnia zbiory polskich bibliotek cyfrowych o dotychczas niezdigitalizowane piśmiennictwo, ale też umożliwia prezentację materiałów zdigitalizowanych i elektronicznych, dokumentujących dorobek uczestniczących w projekcie instytutów wykraczający poza zbiory biblioteczne - oprócz wybranych wydawnictw instytutów, zawiera różnorodną dokumentację badań naukowych (kartoteki, zdjęcia, nagrania), czy też materiały archiwalne.

Zawartość RCIN jest indeksowana przez wyszukiwarkę Google Scholar, Federację Bibliotek Cyfrowych, repozytorium cyfrowe Europeana. Linki do publikacji RCIN dodawane są do opisów bibliograficznych umieszczanych w ogólnopolskim katalogu NUKAT oraz w światowym katalogu WorldCat.

Jak większość bibliotek cyfrowych w Polsce, również RCIN udostępnia swój zasób za pośrednictwem programu dLibra, z użyciem formatu opisu Dublin Core. Każda z publikacji otrzymuje opis w języku polskim i angielskim (ze słowami kluczowymi włącznie). 
Poszczególne instytuty biorące udział w projekcie są prezentowane w kolekcjach na stronie głównej RCIN, oprócz tego mają też wydzielone własne repozytoria. Jednym z nich jest Instytut Historii im. Tadeusza Manteuffla PAN (www.rcin.org.pl/ihpan).

Obecnie repozytorium to zawiera sześć kolekcji, służących przede wszystkim zebraniu w formie cyfrowej wybranej części dorobku Instytutu, przeznaczonej do szerokiej prezentacji w miarę możliwości prawnych:

- książki (opracowania historyczne i wydawnictwa źródłowe z XIX i początków XX w., do których wygasły autorskie prawa majątkowe - należące do tzw. domeny publicznej);

- czasopisma (stopniowo umieszczane są wydawnictwa naukowe z XIX i początków XX w. oraz czasopisma fachowe firmowane przez Instytut Historii PAN: „Acta Poloniae Historica” talnik Historyczny”2 oraz „Studia Źródłoznawcze. Commentationes”3 - w planach są „Dzieje Najnowsze” wraz z poprzednikami, „Odrodzenie i Reformacja w Polsce”, „Studia z Dziejów Rosji i Europy Środkowo-Wschodniej” - dawniej „Studia z Dziejów ZSRR i Europy Środkowej”);

- rękopisy i starodruki (wybrane ze zbiorów Biblioteki IH PAN jako uzupełnienie zasobu Federacji Bibliotek Cyfrowych);

- atlasy historyczne (wydawane przez IH PAN w seriach „Atlasu historycznego Polski”: „Mapy XVIII w.” oraz „Mapy szczegółowe XVI wieku"4);

- Polski Stownik Biograficzny (podstawowe wydawnictwo z dziedziny biografistyki historycznej w Polsce);

- kartoteka Stownika Historyczno-Geograficznego Mazowsza w Średniowieczu (tzw. kartoteka Adama Wolffa, znajdująca się w zbiorach Pracowni Atlasu Historycznego, zawierająca wypisy ze źródeł dotyczących miejscowości na Mazowszu w średniowiecznych i okresie wczesnonowożytnym, uporządkowane wg powiatów i możliwych do ustalenia dzisiejszych nazw miejscowości) ${ }^{5}$.

${ }^{1}$ Jako publikacja wieloczęściowa pod linkiem: http://www.rcin.org.pl/ihpan/publication/3614

2 Jako publikacja wieloczęściowa pod linkiem: http://www.rcin.org.pl/ihpan/publication $/ 3507$

${ }^{3}$ Jako publikacja wieloczęściowa pod linkiem: http://www.rcin.org.pl/ihpan/publication $/ 4040$

${ }^{4} \mathrm{Za}$ wyjątkiem atlasu Województwo lubelskie $w$ drugiej połowie XVI wieku, którego wersja cyfrowa znajduje się już Bibliotece Cyfrowej UMCS.

5 Opis główny kolekcji z wejściem do struktury: http://www.rcin.org.pl/ihpan/publication/35952 
Część publikacji umieszczonych w repozytorium jest objęta ograniczeniem udostępnienia ze względu na ochronę majątkowych praw autorskich. By spełnić wymogi „Ustawy o prawach autorskich i prawach pokrewnych", dotyczących dozwolonego użytku dla bibliotek i instytucji naukowych, są dostępne tylko w sieci lokalnej Instytutu ${ }^{6}$. Fakt ten jest zaznaczony w opisie każdej publikacji.

Aby doprowadzić do udostępnienia publikacji chronionych majątkowym prawem autorskim, Instytut musi zawrzeć umowy licencyjne dotyczące udostępniania w Internecie ze wszystkimi autorami opublikowanych wcześniej drukiem i zawartych w repozytorium utworów naukowych lub z ich spadkobiercami (okres ochrony wynosi 70 lat od roku śmierci autora, udostępnianie zaś w Internecie jest tzw. „nowym polem eksploatacji”, którego nie dotyczyły wcześniejsze umowy zawierane z autorami).

Polski Stownik Biograficzny, z racji na ogromną liczbę autorów i ich spadkobierców, udostępniany jest obecnie tylko w sieci lokalnej IH PAN. W jego prezentacji zdecydowano się na podział na publikacje zbiorowe - tomy odpowiadające drukowanemu oryginałowi, w których właściwymi publikacjami są przeszukiwalne pliki PDF, na ogół mniejsze od drukowanych zeszytów oryginału (w przeciwieństwie do nich biogramy nie są dzielone), oznaczone granicznymi nazwiskami znajdującymi się w danym pliku? .

Roczniki czasopism IH PAN również stanowią publikacje zbiorowe, podzielone na poszczególne właściwe publikacje (artykuły lub artykuły recenzyjne, często pogrupowane również w działy odzwierciedlające układ danego czasopisma) w celu ułatwienia ich udostępniania po uzyskaniu licencji. Krótsze utwory, jak recenzje i notki kronikarskie zawarte są we wspólnych pojedynczych publikacjach odzwierciedlających działy w czasopismach (np. „Recenzje”, „Kronika naukowa”). Wszystkie spisy treści, komunikaty oraz listy do redakcji są dostępne bez ograniczeń.

Fakt objęcia wielu publikacji ochroną praw autorskich znalazł odzwierciedlenie w ich opisie: w polu „Prawa” są one oznaczone „Wszystkie prawa zastrzeżone”, jako właściciele praw zaś wskazani są „Twórcy i Wydawcy".

${ }^{6}$ Ustawa z dnia 4 lutego 1994 roku (tekst jednolity Dz.U. 2006, nr 90, poz. 631 ze zm.). Prawa autorskie są ograniczone w zakresie użytku publicznego, w ramach którego biblioteki, archiwa i szkoły mogą (na podstawie art. 27) udostępniać nieodpłatnie egzemplarz utworów rozpowszechnionych dla celów badawczych lub poznawczych za pośrednictwem końcówek systemu informatycznego (terminali) znajdujących się na terenie tych jednostek. Szerzej na ten temat w publikacji „Seminarium prawne dla bibliotekarzy cyfrowych. Warszawa, 18 czerwca 2010", Warszawa 2010.

${ }^{7}$ Struktura całości dostępna pod linkiem: http://www.rcin.org.pl/ihpan/publication/4137 
Najnowsze numery czasopism, do których udostępniania w Internecie Instytut posiada już prawa, będą udostępniane w repozytorium z zachowaniem okresów karencji ustalonych z ich wydawcami.

Atlasy historyczne, zawierające różnorodne utwory chronione prawem autorskim (są nimi np. wszystkie zawarte w nich mapy), również są udostępniane w zależności od posiadania przez Instytut licencji na ich upowszechnianie w Internecie - obecnie dostępne poza siecią lokalną jest większość atlasów z serii „Mapy szczegółowe XVI wieku”» (Mazowsze, województwo sandomierskie, województwa sieradzkie i łęczyckie, województwo krakowskie oraz województwo płockie). Należą one do najczęściej przeglądanych publikacji z repozytorium IH PAN.

Publikacje, z których właścicielami praw autorskich zostały podpisane licencje, w rubryce „Prawa” oznaczono „Wszystkie prawa zastrzeżone - dostęp nieograniczony”, w rubryce zaś „Prawa dostępu”: „Publikacja dostępna dla wszystkich na własny użytek, do celów naukowych, edukacyjnych lub dydaktycznych". Pozostałe utwory oznaczone są w rubryce Prawa: „Prawa zastrzeżone - dostęp ograniczony”, zaś w Prawach dostępu: „Publikacja dostępna w sieci Instytutu Historii PAN na własny użytek, do celów naukowych, edukacyjnych lub dydaktycznych".

Pozyskiwanie licencji jest żmudnym i niekiedy skomplikowanym procesem, który potrwa jeszcze wiele lat i w wielu przypadkach nie zostanie zakończony sukcesem. Do repozytorium dodawane są wciąż nowe publikacje, autorzy zaś, którzy podpisali licencję z Instytutem są jeszcze w mniejszości. Warto zauważyć, że ze względu na obecność zasobów RCIN w najważniejszych wyszukiwarkach oraz dwujęzyczny opis publikacji, mogą oni liczyć na znaczące ułatwienie w prezentacji ich dorobku naukowego szerokiemu gronu czytelników. W przypadku utworów dostępnych tylko w sieci lokalnej, RCIN spełnia rolę rozbudowanej bazy bibliograficznej.

RCIN może w przyszłości pełnić funkcję głównej platformy prezentującej bieżącą produkcję naukową Instytutu w formie elektronicznej oraz służyć badaczom zainteresowanym publikowaniem swych prac w tej formie. Może służyć dokumentacji międzyinstytucjonalnych projektów badawczych, dokumentacyjnych i edytorskich, realizowanych czy to z wykorzystaniem zdigitalizowanych cennych zbiorów należących do osób prywatnych czy to innych instytucji naukowych lub kulturalnych.

8 Jako publikacja wieloczęściowa seria dostępna pod linkiem: http://www.rcin. org.pl/publication/6733 
$\mathrm{Na}$ koniec warto dodać, że RCIN może służyć również jako platforma wymiany publikacji naukowych w wersji elektronicznej - dostęp do publikacji w RCIN może być oczywiście możliwy na takich samych zasadach udostępniania, jak w IH PAN, czyli w lokalnej sieci danej instytucji, identyfikowanej wg numeru IP. 
